Jurnal Ilmu Sosial dan Pendidikan (JISIP)

Vol. 6, No. 1 Januari 2022

e-ISSN : 2656-6753, p-ISSN: 2598-9944

DOI: 10.36312/jisip.v6i1.2794/http://ejournal.mandalanursa.org/index.php/JISIP/index

\title{
Model Altman Untuk Menilai Kinerja Perusahaan Subsektor Pertambangan Batubara Periode 2015-2019
}

\author{
Agus Munandar ${ }^{1}$, Herman Hidayat ${ }^{2}$, Ramdani $^{3}$ \\ ${ }^{1}$ Magister Akuntansi, Fakultas Ekonomi Dan Bisnis, Universitas Esa Unggul \\ ${ }^{2}$ Manajemen, Fakultas Ekonomi Dan Bisnis, Universitas Esa Unggul \\ ${ }^{3}$ Manajemen, Fakultas Ekonomi Dan Bisnis, Universitas Esa Unggul
}

\section{Article Info}

Article history:

Received 03 Januari 2022

Publish 07 januari 2022

\section{Keywords:}

Financial Distress

Altman Z-Scor

Coal

\section{Info Artikel}

Article history:

Diterima 03 Januari 2022

Publis 07 Januari 2022

\begin{abstract}
This study aims to determine the degree of accuracy of the Altman Z-score method in predicting the bankruptcy of a company. This study uses quantitative research with a descriptive approach through accuracy and error type tests. Where the samples used are companies that are members of the coal mining sub-sector during the 2015-2019 period. Purposive sampling method was used in sampling with a total sample of 19 companies. The Altman Z-score method has an accuracy rate and type error of $11 \%$ and $42 \%$, which indicate that the method is not good for use in companies that are members of the coal mining sub-sector.
\end{abstract}

\begin{abstract}
Penelitian ini bertujuan untuk mengetahui keakuratan metode Altman Z-score dalam memprediksi tingkat kebangkrutan suatu perusahaan. Penelitian ini menggunakan penelitian kuantitatif dengan metode deskriptif melalui pengujian akurasi dan tipe kesalahan. Sampel yang digunakan adalah perusahaan yang tergabung dalam subsektor pertambangan batubara selama periode 2015-2019. Metode purpose sampling digunakan untuk sampel 19 perusahaan. Jenis akurasi dan error dari metode Altman Z-score masing-masing sebesar $11 \%$ dan $42 \%$, yang menunjukkan bahwa metode tersebut tidak diterapkan dengan baik pada perusahaan yang tergabung dalam subsektor pertambangan batubara.
\end{abstract}

This is an open access article under the Lisensi Creative Commons AtribusiBerbagiSerupa 4.0 Internasional

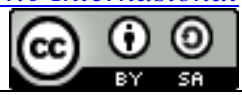

\section{Corresponding Author:}

Agus Munandar,

Universitas Esa Unggul

Email: agus.munandar@esaunggul.ac.id

\section{PENDAhULUAN}

Globalisasi dan perkembangan teknologi yang pesat memaksa bisnis untuk beroperasi lebih intens dalam lingkungan yang kompetitif. Oleh karena itu, penentuan risiko bisnis dan manajemen risiko yang efektif menjadi elemen penting untuk kesuksesan jangka panjang. Manajemen risiko yang efektif memerlukan identifikasi masalah, penilaian, dan prioritas risiko atau ketidakpastian, serta mitigasi, pemantauan, dan pengendalian konsekuensi risiko. Dalam konteks ini, memprediksi kesulitan keuangan dan menentukan faktor-faktor yang mempengaruhi kegagalan keuangan menjadi semakin penting bagi bisnis (Miller, 2009). Fakta bahwa bisnis telah berada dalam lingkungan yang sangat kompetitif dalam beberapa tahun terakhir membuat bisnis sulit untuk beroperasi di seluruh dunia. Contoh kecil dari risiko financial distress, seperti kerugian usaha 
dan/atau perusahaan mengalami masalah likuiditas, dapat berdampak lebih parah pada perusahaan dan berisiko bangkrut dan likuidasi bisnis jika tidak diambil keputusan yang bijak (Nguyen \& Fa, 2010).

Laporan keuangan perusahaan dapat menunjukkan permasalahan keuangan yang dapat menyebabkan penurunan kinerja hingga kepailitan. Financial Distress yang terjadi pada satu perusahaan merupakan suatu keadaan yang mengerikan yang dialami dalam keuangan perusahaan, terutama hal-hal yang mengacu pada kesehatan keuangan perusahaan. Investor berpotensi cemas dengan kondisi perusahaan yang akan diinvestasikannya. Jadi, pada dasarnya rasio keuangan perusahaan sangat penting bagi mereka ketika hendak menginvestasikan uangnya di perusahaan. (Jordan, dkk, 2008) mendefinisikan bahwa financial distress sebagai situasi dimana arus kas operasional tidak mampu menutupi syarat obligasi, sehingga diperlukan Tindakan segera oleh manajemen.

Kebangkrutan juga diprediksi melalui laporan keuangan perusahaan. Kinerja keuangan adalah pernyataan kinerja ekonomi perusahaan dari pencapaiannya selama periode waktu tertentu. Bisnis saat ini menilai prediksi kebangkrutan sebagai masalah penting. Prediksi kebangkrutan yang tepat, memberikan catatan yang sangat penting bagi perusahaan untuk mengevaluasi risiko atau mencegah terjadinya kebangkrutan. Memprediksi financial distress merupakan metode yang cukup ampuh untuk membantu perusahaan dan investor dalam mengambil keputusan yang bijak. Memprediksi sebelum terjadinya financial distress membantu perusahaan melakukan tindakan preventif agar perusahaan tidak terkena kondisi financial distress.

Kebangkrutan tidak dapat disangkal adalah situasi mengerikan yang sering muncul pada sector pertambangan. Subsektor pertambangan batubara dianggap sebagai salah satu bidang yang paling berkontribusi dalam pembangunan ekonomi secara nasional, salah satu perannya yaitu sebagai penyedia bahan baku energi untuk peningkatan ekonomi nasional. Untuk menggali sumber daya dalam pengembangan pertambangan, perusahaan pertambangan membutuhkan kekuatan finansial yang besar.

Menurut (Salim, 2016) fenomena kebangkrutan yang terjadi di industri pertambangan batubara Indonesia sudah terindikasi sejak tahun 2011 dimana harga jual komoditas batubara turun, juga kenaikan biaya produksi yang signifikan. Perusahaan batubara mengalami berbagai tekanan pasar yang berujung pada kebangkrutan, mengalami insufisiensi, tidak mampu mendanai biaya operasional yang besar, dan harga batubara global sejak 2011 juga tidak hanya meningkat tetapi juga diduga cenderung menurun. (Salim, 2016)

Perusahaan sub sektor pertambangan batubara yang bangkrut karena kesulitan keuangan akhirnya dihadapkan pada risiko kerugian yang besar, sehingga delisting di Bursa Efek Indonesia. Delisting yaitu suatu proses pengeluaran perusahaan dari bursa yang dilakukan oleh badan otoriras bursa itu sendiri. Perusahaan dapat melakukan proses delisting dengan delisting secara sukarela atau delisting paksa. Biasanya proses delisting terjadi karena perusahaan tidak lagi aktif beroperasi, dinyatakan pailit, penggabungan perusahaan, tidak lagi sesuai dengan ketentuan bursa, atau memutuskan untuk menjadi perusahaan tertutup.

Terjadinya fenomena ini akan berakibat perusahaan agar lebih memiliki prinsip kehati-hatian didalam mengelola perusahaannya, terutama dalam mengelola kondisi keuangan perusahaan. Subjek penelitian ini, yaitu kesulitan keuangan, yang telah menjadi subjek penelitian dan diskusi yang intens oleh para ekonom, bankir, kreditur, pemegang saham, akuntan, dan manajemen. Dampak kesulitan keuangan yang besar dapat mempengaruhi pemegang saham, kreditur, pemerintah, dan sebagainya. Hal ini menuntut perusahaan untuk terus memantau kegiatan mereka untuk mencegah kemungkinan kebangkrutan. Oleh karena itu, diperlukan suatu instrumen untuk dapat memprediksi potensi kondisi financial distress. Semakin dini tanda-tanda kebangkrutan dapat diidentifikasi, semakin bagus untuk perusahaan. Perusahaan bisa mengambil langkah-langkah antisipasi agar perusahaan tidak mengarah pada kebangkrutan. (Salim, 2016) 
Penelitian tentang prediksi kebangkrutan pertama kali dilakukan oleh (Beaver, 1966), dan selanjutnya dilakukan oleh (Altman, 1968) sehingga terciptalah model prediksi kebangkrutan yang disebut model penelitian Altman Z. Penelitian yang dilakukan oleh Beaver dan Altman ini dilatarbelakangi oleh banyaknya perusahaan yang bangkrut pada tahun 1960-an di Amerika Serikat. Model untuk memprediksi kebangkrutan terus berkembang setelah tahun 1970-an, baik dari segi bentuk struktural, formula, sistem analisis, dan sampel, seperti Model Probit Zmijewski, Model Springate, Model Grover, Model Ohlson Logit, Model Fulmer, Model Shumway Hazard. Untuk memprediksi kebangkrutan sedini mungkin, model-model ini memberikan tingkat akurasi yang berbeda berdasarkan pengukuran yang digunakan.

\section{TINJAUAN PUSTAKA}

\subsection{Financial Distress}

Konsep financial distress dalam status keuangan suatu perusahaan adalah kondisi perusahaan menghadapi kesulitan keuangan atau kehilangan kemampuan untuk mendanai investor atau krediturnya. Diyakini bahwa sebagian besar kegagalan bisnis terkait dengan kesulitan keuangan. Dapat disimpulkan bahwa financial distress mengacu pada suatu keadaan dimana suatu perusahaan mengalami kesulitan keuangan yang cukup besar dan dapat menyebabkan perusahaan tersebut bangkrut (Achsani et al., 2010).

Menurut (Isayas, 2021) suatu perusahaan mengalami kesulitan keuangan ketika terjadi pelanggaran kewajiban kontraktual hutang, ketika organisasi mengalami kerugian bisnis yang berkelanjutan, dan gagal memenuhi kewajiban yang jatuh tempo. Ketika suatu perusahaan mengalami kesulitan keuangan, maka kegiatan operasional perusahaan juga semakin memburuk sehingga menimbulkan beban keuangan yang berat bagi perusahaan yang berakibat pada ketidakmampuan perusahaan untuk mendanai kewajibannya (Chancharat, 2008). (Wesa, EW, \& Otinga, 2018) mencatat bahwa perusahaan yang mengalami financial distress biasanya dihadapkan pada dua kemungkinan masalah yaitu mengalami kekurangan kas atau kewajiban yang telah jatuh tempo dari posisi laporan keuangan. Dampak negatif dari kesulitan keuangan suatu perusahaan mengancam kelangsungan hidup perusahaan karena dapat mengarah pada kebangkrutan.

\subsection{Kepailitan}

Kepailitan biasanya diartikan sebagai suatu keadaan dimana suatu perusahaan mengalami pailit atau tidak mampu lagi memenuhi kewajiban debiturnya karena kekurangan dan ketidakcukupan dana perusahaan (Ningsih \& Permatasari, 2019). Kebangkrutan biasanya bermula dari kesulitan keuangan dan, sebagai kondisi akhir, dimulai dengan kegagalan perusahaan untuk memenuhi kewajibannya, faktor ekonomi, salah urus, atau bencana alam. Kebangkrutan juga dapat diartikan sebagai kegagalan perusahaan dalam menjalankan operasi perusahaan untuk menghasilkan keuntungan, yang ditandai dengan kesulitan keuangan, yang membuat perusahaan tidak dapat menjalankan kegiatan usahanya secara normal.

\subsection{Altman Z-score}

Studi multivariat pertama kali diterbitkan oleh Altman (1968). Altman Z-score merupakan salah satu metode untuk mengetahui tingkat kesehatan keuangan suatu perusahaan yang dapat digunakan untuk menilai keberhasilan atau kegagalan pengelolaan suatu perusahaan. Altman menggunakan Analisis Diskriminan Multivariat (MDA) untuk mengembangkan model lima faktor untuk memprediksi kebangkrutan. Z-score memprediksi kebangkrutan ketika skor perusahaan berada dalam kisaran kriteria tertentu.

\section{METODE PENELITIAN}

Penelitian ini dilakukan pada 19 perusahaan sub sektor pertambangan batubara yang terdaftar di BEI periode 2015 - 2019. jumlah perusahaan dalam penelitian ini adalah 19 perusahaan selama 
periode 2015 - 2019. Metode purposive sampling digunakan dalam penelitian ini untuk pemilihan sampel. Purposive sampling adalah teknik pengambilan sampel sumber data dengan perbandingan tertentu (Sugiyono, 2015).

Model Z-Score menggunakan analisis diskriminan multivariat untuk memilih lima variabel yang paling signifikan untuk mengukur kesulitan keuangan perusahaan dimana kategori rasio standar adalah: likuiditas, profitabilitas, leverage, solvabilitas, dan aktivitas (Altman, 1968). Rasio ini dipilih berdasarkan popularitasnya dalam literatur dan potensi relevansinya untuk penelitian ini.

Fungsi MDA yang dilakukan oleh (Altman, 1968) adalah sebagai berikut:

Sedangkan:

$$
\mathrm{Z}=6.56 \mathrm{X} 1+3.26 \mathrm{X} 2+6.72 \mathrm{X} 3+1.05 \mathrm{X} 4
$$

$\mathrm{Z} \quad=$ Indeks Keseluruhan (Altman Z-score)

X1 = Modal Kerja terhadap Total Aktiva

X2 = Laba Ditahan Terhadap Total Aset

$\mathrm{X} 3=$ Laba Sebelum Pajak Penghasilan (EBIT) terhadap Total Aset

$\mathrm{X} 4 \quad=$ Nilai Buku Ekuitas terhadap Total Kewajiban

Tabel 1. Kriteria Penilaian Z-score

\begin{tabular}{|r|l|}
\hline Z Score & Descriptions \\
\hline$<1.10$ & High probability of bankruptcy \\
\hline $1.10-2.60$ & Bankruptcy is not predictable \\
\hline$>2.60$ & No probability of bankruptcy \\
\hline
\end{tabular}

Sumber; Altman, 1968

Dari tabel di atas diketahui bahwa;

1. Perusahaan bangkrut, jika nilai $\mathrm{Z}$ dibawah 1,10

2. Perusahaan berada pada wilayah $a b u$ abu karena tidak dapat dikatakan bangkrut atau sehat jika mendapat skor $1,10-2,60$

3. Perusahaan sehat, jika nilai $\mathrm{Z}$ lebih dari 2.60

\section{HASIL PENELITIAN DAN PEMBAHASAN}

Berikut ini dilampirkan hasil perhitungan yang telah dilakukan penulis berdasarkan data laporan keuangan tahunan perusahaan pertambangan batubara periode 2015-2019 :

Tabel 2. Hasil Perhitungan Metode Altman

\begin{tabular}{|c|c|c|c|c|c|c|}
\hline \multirow{2}{*}{ No } & \multirow{2}{*}{ Emiten } & \multicolumn{5}{|c|}{ Tahun } \\
\cline { 3 - 7 } & & $\mathbf{2 0 1 5}$ & $\mathbf{2 0 1 6}$ & $\mathbf{2 0 1 7}$ & $\mathbf{2 0 1 8}$ & $\mathbf{2 0 1 9}$ \\
\hline 1 & ADRO & Bangkrut & Abu-abu & Abu-abu & Abu-abu & Bangkrut \\
\hline 2 & ARII & Bangkrut & Bangkrut & Bangkrut & Bangkrut & Bangkrut \\
\hline 3 & BRMS & Bangkrut & Bangkrut & Bangkrut & Bangkrut & Bangkrut \\
\hline 4 & BSSR & Abu-abu & Abu-abu & Sehat & Sehat & Bangkrut \\
\hline 5 & BUMI & Bangkrut & Bangkrut & Bangkrut & Bangkrut & Bangkrut \\
\hline 6 & BYAN & Bangkrut & Abu-abu & Sehat & Sehat & Abu-abu \\
\hline 7 & DEWA & Bangkrut & Bangkrut & Bangkrut & Bangkrut & Bangkrut \\
\hline 8 & DOID & Bangkrut & Abu-abu & Abu-abu & Abu-abu & Bangkrut \\
\hline
\end{tabular}




\begin{tabular}{|c|c|c|c|c|c|c|}
\hline 9 & GEMS & Abu-abu & Abu-abu & Sehat & Sehat & Abu-abu \\
\hline 10 & HRUM & Bangkrut & Abu-abu & Abu-abu & Abu-abu & Abu-abu \\
\hline 11 & ITMG & Abu-abu & Abu-abu & Sehat & Sehat & Abu-abu \\
\hline 12 & KKGI & Abu-abu & Abu-abu & Abu-abu & Bangkrut & Abu-abu \\
\hline 13 & MBAP & Sehat & Sehat & Sehat & Sehat & Sehat \\
\hline 14 & MYOH & Abu-abu & Sehat & Abu-abu & Sehat & Sehat \\
\hline 15 & PKPK & Bangkrut & Bangkrut & Bangkrut & Bangkrut & Bangkrut \\
\hline 16 & PTBA & Abu-abu & Abu-abu & Abu-abu & Abu-abu & Abu-abu \\
\hline 17 & PTRO & Bangkrut & Bangkrut & Bangkrut & Abu-abu & Abu-abu \\
\hline 18 & SMMT & Bangkrut & Bangkrut & Bangkrut & Bangkrut & Bangkrut \\
\hline 19 & TOBA & Abu-abu & Abu-abu & Abu-abu & Abu-abu & Abu-abu \\
\hline
\end{tabular}

Sumber : olah data, 2021

Berdasarkan pengolahan dengan metode altman z-score diketahui bahwa rata-rata perusahaan yang bergabung dalam subsektor pertambangan batubara berada dalam wilayah bangkrut. Hal ini mengindikasikan bahwa subsektor pertambangan batu bara merupakan salah satu sektor yang sangat riskan dipilih oleh para investor, dengan berada di wilayah bangkrut, tidak tertutup kemungkinan investor tidak akan mendapatkan tingkat pengembalian atas nilai investasi yang telah mereka lakukan.

Dari total sembilan belas sampel perusahaan, terlihat bahwa sembilan perusahaan masuk ke dalam kriteria abu-abu, dua perusahaan termasuk dalam kriteria sehat dan tujuh perusahaan termasuk ke dalam kriteria bangkrut. Sementara satu perusahaan tidak dihitung karena masingmasing dalam kriteria abu-abu atau bangkrut. Sembilan perusahaan yang termasuk kedalam kriteria abu-abu yaitu ADRO, BYAN, DOID, GEMS, HRUM, ITMG, KKGI, PTBA dan TOBA. ADRO selama periode penelitian mengalami penurunan pendapatan yang diakibatkan menurunnya jumlah penjualan yang dilakukan oleh perusahaan. BYAN selama periode penelitian mengalami penurunan yang besar pada kemampuan perusahaan dalam menghasilkan modal kerja bersih dari seluruh total aset yang dimiliki. DOID mengalami penurunan yang besar pada kemampuan perusahaan dalam memenuhi beberapa kewajiban dari nilai pasar modal sendiri (saham biasa) selama periode penelitian. GEMS mengalami penurunan pada kemampuan perusahaan dalam menghasilkan modal kerja bersih dari seluruh total aset yang dimiliki selama periode penelitian. HRUM selama periode penelitian kurang optimal dalam kemampuan perusahaan dalam menghasilkan laba dari aset perusahaan. ITMG, KKGI, PTBA dan TOBA hampir semua mengalami penurunan dari mulai kemampuan menghasilkan laba maupun kemampuan memenuhi beberapa kewajibannya selama periode penelitian.

Untuk dua perusahaan yang termasuk kedalam kriteria sehat yaitu MBAP dan MYOH, selama periode penelitian memiliki kinerja perusahaan yang baik, meliputi kemampuan perusahaan dalam menghasilkan modal kerja bersih dari seluruh total aset yang dimiliki, kemampuan perusahaan dalam menghasilkan laba ditahan dari total aset perusahaan, kemampuan perusahaan dalam menghasilkan laba dari aset perusahaan, sebelum pembayaran bunga dan pajak dan kemampuan perusahaan dalam memenuhi beberapa kewajiban dari nilai pasar modal sendiri (saham biasa).

Sementara sembilan perusahaan yang masuk kriteria bangkrut, yaitu ARII, BRMS, PKPK dan BUMI selama periode penelitian memiliki kinerja perusahaan yang buruk, meliputi kemampuan perusahaan dalam menghasilkan modal kerja bersih dari seluruh total aset yang dimiliki, kemampuan perusahaan dalam menghasilkan laba ditahan dari total aset perusahaan, kemampuan perusahaan dalam menghasilkan laba dari aset perusahaan, sebelum pembayaran 
bunga dan pajak dan kemampuan perusahaan dalam memenuhi beberapa kewajiban dari nilai pasar modal sendiri (saham biasa). Untuk DEWA, PTRO dan SMMT selama periode penelitian mengalami kinerja yang buruk pada kemampuan perusahaan dalam menghasilkan modal kerja bersih dari seluruh total aset yang dimiliki.

Setelah diketahui metode perhitungan prediksi Altman Z-score, selanjutnya dihitung tingkat akurasi dan jenis kesalahannya. Berikut adalah hasil perhitungannya;

Tabel 3. Hasil Perhitungan Metode Altman

\begin{tabular}{|c|c|c|c|c|}
\hline \multirow{2}{*}{ Deskripsi } & \multicolumn{3}{|c|}{ Prediksi } & \multirow[b]{2}{*}{ Tota } \\
\hline & Bangkrut & Abu-abu & Sehat & \\
\hline $\begin{array}{l}\text { Metode Perhitungan Altman Z- } \\
\text { score }\end{array}$ & 8 & 9 & 2 & 19 \\
\hline $\begin{array}{c}\text { Perusahaan riil tidak mengalami } \\
\text { kebangkrutan }\end{array}$ & & & & 19 \\
\hline Accuracy Rate & & & & $11 \%$ \\
\hline Type Error & & & & $42 \%$ \\
\hline Gray Area & & & & $47 \%$ \\
\hline
\end{tabular}

Sumber: Hasil Penelitian, 2021

Dimana :

Tingkat Akurasi $=\frac{\text { Jumlah Prediksi yang Benar }}{\text { Jumlah Sampel }} \times 100 \%$

Jenis Kesalahan $\quad=\frac{\text { Jumlah Kesalahan }}{\text { Jumlah Sampel }} \times 100 \%$

Berdasarkan pengolahan data yang sudah dilakukan, dapat diketahui bahwa dari sebanyak 19 perusahaan, metode Altman Z-score menunjukkan ada sebanyak 2 perusahaan dikatakan sehat atau dengan kata lain tingkat akurasi yang menyatakan bahwa sebanyak 2 perusahaan yang dinyatakan sehat adalah sebesar $11 \%$. Masih dengan menggunakan metode Altman Z-score, didapatkan tingkat jenis kesalahan perhitungan adalah sebesar $42 \%$ dengan jumlah perusahaan yang dinyatakan bangkrut sebanyak 8 perusahaan, dan sebanyak 9 perusahaan berada pada area abu-abu, tidak dinyatakan bangkrut maupun sehat sebesar $47 \%$.

Perusahaan mengalami financial distress padahal sebenarnya tidak mengalami financial distress. Artinya, dalam memprediksi perusahaan dengan kondisi riill tidak mengalami financial distress model Altman. Jika investor mempercayai model Altman maka investor bisa kehilangan kesempatan untuk berinvestasi karena model Altman memprediksi perusahaan sehat kedalam kategori perusahaan yang mengalami kondisi keuangan buruk, hal ini akan menimbulkan opportunity cost bagi investor.

Perhitungan dengan metode Altman Z-score ternyata memiliki kelemahan untuk dapat menggambarkan keadaan perusahaan yang sebenarnya, seperti yang sudah disebutkan diatas, bahwa sebanyak 8 perusahaan dinyatakan bangkrut tidak tepat, karena pada kenyataannya hingga saat ini, ke 8 perusahaan itu tetap eksis berada di bursa.

\section{KESIMPULAN}

Berdasarkan pembahasan dari sebelumnya, dapat dikatakan bahwa metode Altman Z-score kurang tepat digunakan di perusahaan-perusahaan subsektor pertambangan batubara karena jika dilihat selama periode penelitian tidak tertutup adanya kesalahan perusahaan dalam melakukan kesalahan pencatatan dalam pelaporan keuangannya, hal ini yang dapat menyebabkan metode 
Altman Z-score tidak akurat dalam penentuan kinerja perusahaan yang sebenarnya, sehingga ada baiknya tidak hanya menggunakan satu metode dalam memprediksi kinerja perusahaan.

\section{DAFTAR PUSTAKA}

Achsani, NA, Manurung, AH, \& Nuryartono, N. (2010). Dinamika Corporate Financial Distress pada Emerging Market Economy : Dinamika Corporate Financial Distress pada Emerging Market Economy : Bukti Empiris dari Bursa Efek Indonesia 2004-2008. Agustus 2014.

Altman, EI (1968). RASIO KEUANGAN, ANALISIS DISKRIMINAN DAN PREDIKSI KEBANGKITAN PERUSAHAAN. Jurnal Keuangan, 23(4), 589-609. https://doi.org/https://doi.org/10.1111/j.1540-6261.1968.tb00843.x

Beaver, WH (1966). Rasio Keuangan Sebagai Prediktor Kegagalan. Jurnal Penelitian Akuntansi, 4, 71-111. https://doi.org/10.2307/2490171

Chancharat, N. (2008). Kumpulan Tesis Universitas Wollongong Analisis empiris perusahaan Australia yang mengalami kesulitan keuangan: penerapan analisis kelangsungan hidup Nongnit Chancharat.

Isayas, YN (2021). Kesulitan keuangan dan faktor penentunya : Bukti dari perusahaan asuransi di Ethiopia Kesulitan keuangan dan faktor penentunya : Bukti dari perusahaan asuransi di Ethiopia. Bisnis \& Manajemen yang Cogent, 8(1). https://doi.org/10.1080/23311975.2021.1951110

Jaffe Jordan, Bradford D., Ross, Stephen A., Westerfield, Randolph W., JF (2008). Manajemen keuangan modern. McGraw-Hill/Irwin.

Miller, W. (2009). Salinan elektronik tersedia di: http://ssrn.com/abstract=1516762. Desember.

Nguyen, H., \& Faff, R. (2010). Apakah perusahaan melakukan lindung nilai atau berspekulasi? Hubungan antara derivatif keuangan dan risiko perusahaan. Ekonomi Keuangan Terapan, 20(10), 827-843. https://econpapers.repec.org/RePEc:taf:apfiec:v:20:y:2010:i:10:p:827-843

Ningsih, S., \& Permatasari, FF (2019). Model X-Score Zmijewski Untuk Memprediksi Kesulitan Keuangan Pada Perusahaan Go Public Sub Sektor Otomotif Dan Komponennya. 19(02), 134-140.

Prof.Dr.Sugiyono. (2015). Metode penelitian pendidikan (pendekatan kuantitatif, kualitatif dan r\&d.

Salim, MN (2016). Potensi Kebangkrutan Perusahaan Pertambangan Batubara Yang Terdaftar di BEI Dengan Pendekatan Model Altman, Springate dan Zmijewski Periode 2011-2014. Economic Journal, 18(3) , 376-396.

Wesa, EW, \& Otinga, H. (2018). DETERMINAN KESULITAN KEUANGAN ANTARA PERUSAHAAN YANG TERDAFTAR DI BURSA EFEK NAIROBI, KENYA Strategic Journal of Business \& Change Management, 5(4), 1056-1073. 